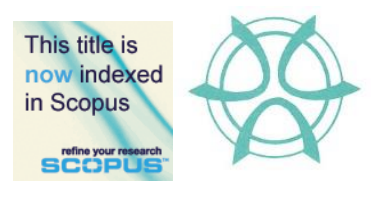

PLANNING MALAYSIA:

Journal of the Malaysian Institute of Planners

VOLUME 15 ISSUE 3 (2017), Page 170 - 178

\title{
DETERMINING BARRIERS IN SUSTAINABLE REFURBISHMENT PROJECTS: COMMERCIAL BUILDING OWNER PERSPECTIVES
}

\author{
Md Asrul Nasid Masrom ${ }^{1}$, Mohd Hilmi Izwan Abd Rahim ${ }^{2}$, Siow Chan Ann',

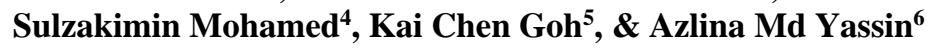 \\ ${ }^{1,2,3,4,5,6}$ Faculty of Technology Management and Business \\ UNIVERSITI TUN HUSSEIN ONN MALAYSIA
}

\begin{abstract}
Existing commercial buildings in Malaysia account for one third of the total electricity consumption. They present a great opportunity for refurbishment to reduce carbon dioxide. However, sustainably refurbished commercial buildings that is Green Building Index (GBI) certified is still low. This study aims to investigate barriers that impede commercial building owners to implement sustainable refurbishment and explore ways to increase numbers of sustainable refurbishment implementation. Qualitative data were collected through semistructured interviews. The respondents were commercial building owners' representative, who were mainly building managers. The findings indicated that higher cost of sustainable refurbishment than conventional method and lacking of sustainability awareness among Malaysian were the main barriers of sustainable refurbishment. This study will be useful in helping building owners and developers to enhance economic, social and environmental benefits of sustainable refurbishment.
\end{abstract}

Keyword: Sustainable refurbishment, commercial building, Malaysia, sustainability, barriers

Date Received: $1^{\text {st }}$ November 2016

Date of Acceptance: $21^{\text {st }}$ October 2017 
Md Asrul Nasid Masrom, Mohd Hilmi Izwan, Siow Chan Ann, Sulzakimin M, Kai Chen Goh, \& Azlina

Determining Barriers in Sustainable Refurbishment Projects: Commercial Building Owner Perspectives

\section{INTRODUCTION}

Building refurbishment becomes more significant with several 1960s and 1970s buildings now become less efficient and ready to be reconstructed. Besides, sustainable refurbishment plays an important role in the global fight against climate change. In the year 2009, Malaysia launched the National Green Technology policy with one of the main objectives was to minimize growth of energy consumption while enhancing economic development (Bruce et al., 2015). In spite of the efforts that have done by the government, Malaysia commercial buildings are still accounted for 39 terawatt hour $\left(10^{12} \mathrm{Wh}\right)$ of electricity, which also equivalent to one third of the total electricity consumption in Malaysia (CIDB, 2015). This high consumption of electricity contributed to climate change in the form of carbon dioxide emission at power generating facilities. Therefore, sustainable refurbishment (Energy Commission, 2013) could increase efficiency of these old buildings, hence reduce electricity consumption and impact to the environment.

However, the current sustainable building movement only focuses on developing new green building but not sustainable refurbishment on the existing buildings. Things were made worse when refurbishment of existing building, despite being undertaken, did not take into account the need for sustainability. Although there were at least 1,000 refurbishment projects each year for the last 3 years (Green Building Index Organization, 2015), only 9 existing buildings that are GBI certified after being sustainably refurbished (Energy Commission, 2013).

Although the benefits of the sustainable refurbishment have been mentioned widely in terms of reducing operating cost, reducing $\mathrm{CO}_{2}$ emissions and so on, commercial building owners remain unfavourable to sustainably refurbish their buildings. Therefore, this study aims to identify the barriers that impede commercial building owners to implement sustainable refurbishment by using qualitative approach.

\section{RESEARCH GAP- CURRENT SCENARIO OF SUSTAINABLE REFURBISHMENT}

This section discusses on sustainable refurbishment of commercial building and barriers of sustainable refurbishment.

\section{Refurbishment}

Haeyeon (2014) defines refurbishment as extending the usefulness of existing building through the adaptation of their basic forms to provide a new or updated version of the original structure. Similarly, Keivani et al. (2005) state that refurbishment as the extensive renewal or modification of secondary elements of a building that may be required to adapt the structure to new purpose. Other terms that are commonly used to define refurbishment include conversion, retrofit, rehabilitation, adaptation, renovation and restoration. 
PLANNING MALAYSIA

Journal of the Malaysia Institute of Planners (2017)

\section{Existing Commercial Building in Malaysia}

According to Bruce et al. (2015), Malaysia currently possesses an existing commercial buildings stock of more than 5,000 buildings, which consists of 904 buildings of shopping complex, more than 2,400 buildings of purpose-built offices and around 2,800 hotels. These huge amount of commercial building stocks are one of the key elements for reducing carbon dioxide emissions.

\section{Barriers of Sustainable Refurbishment}

Although each and every year there have been a considerable number of refurbishment projects in Malaysia, there are only few projects that can be classified as sustainable refurbishment of buildings. Scholars have identified several significant barriers that impede commercial building owners from implementing sustainable refurbishment, which include aspects of financial, technical and social, as well as regulation on sustainable development.

Table 1 Barriers of sustainable refurbishment

\begin{tabular}{|c|c|}
\hline $\begin{array}{l}\text { Authors, Year } \\
\text { (Location) }\end{array}$ & Barriers \\
\hline $\begin{array}{l}\text { Leench \& } \\
\text { Onwiegbuzie, } \\
2007 . \\
\text { (Australia) }\end{array}$ & $\begin{array}{l}\text { - More expensive to retrofit and always contain various hidden costs. } \\
\text { - Recent development building code in the area of fire safety and } \\
\text { disability access, prevent a lot of buildings from ever being re-used. } \\
\text { - Lack of awareness and expertise with regard to best use of property. } \\
\text { - Long payback period. }\end{array}$ \\
\hline $\begin{array}{l}\text { Miller \& Buys, } \\
2008 . \\
\text { (Finland) }\end{array}$ & $\begin{array}{l}\text { - Limitation of the transformation of the space. } \\
\text { - Relatively small budget and short time frame of refurbishment projects } \\
\text { than new construction. } \\
\text { - The condition of existing building is difficult to evaluate. }\end{array}$ \\
\hline $\begin{array}{l}\text { NAPIC, } 2014 . \\
\text { (Australia) }\end{array}$ & $\begin{array}{l}\text { - Sustainable retrofit or technology upgrade requires the cooperation and } \\
\text { participation of a wide range of stakeholders. }\end{array}$ \\
\hline $\begin{array}{l}\text { NAPIC, } 2012 . \\
\text { (Malaysia) }\end{array}$ & $\begin{array}{l}\text { - Lack of awareness among the client on the long-term financial benefit } \\
\text { of building green. } \\
\text { Most of the stakeholders mainly priorities on economic issues rather } \\
\text { than taking a balanced approach to economic, environment and social } \\
\text { sustainability. }\end{array}$ \\
\hline $\begin{array}{l}\text { Prodomou, } \\
2010 . \\
\text { (United } \\
\text { Kingdom) }\end{array}$ & $\begin{array}{l}\text { - High upfront costs discourages sustainable refurbishment. } \\
\text { - Disconnection between costs and benefits where owner bear the costs } \\
\text { and lower energy costs accrue only to tenants. } \\
\text { - Lack of knowledge and experienced workforce }\end{array}$ \\
\hline
\end{tabular}

\section{RESEARCH METHODOLOGY}

The targeted respondents were commercial building managers located in Kuala Lumpur. This research was conducted to collect the qualitative data through interview with existing commercial building managers who had managed the implementation of building refurbishment. A pilot test was conducted to detect 
Md Asrul Nasid Masrom, Mohd Hilmi Izwan, Siow Chan Ann, Sulzakimin M, Kai Chen Goh, \& Azlina

Determining Barriers in Sustainable Refurbishment Projects: Commercial Building Owner Perspectives

weaknesses in design and instrumentation and to provide proxy data for selection of a probability sample (Riley \& Cotgrave, 2005). The interview questions were then asked to commercial building managers, of which two of them have had managed GBI certified sustainable refurbishment of their buildings and another two without experience of sustainable refurbishment. Data from the interviews were analysed using content analysis to identify underlying themes presented through the data (Sunil, 2012).

\section{DATA ANALYSIS AND RESULTS}

\section{Respondents Background}

Respondents that were selected for the interview in this study were managerial employees from four different commercial office buildings in Kuala Lumpur. Table 2 shows the profiles of the four selected respondents of this study.

Table 2: Respondents Detail's

\begin{tabular}{|c|c|c|c|c|}
\hline Respondent & $\begin{array}{c}\text { GBI } \\
\text { Certified } \\
\text { (NREB) }\end{array}$ & $\begin{array}{l}\text { Working } \\
\text { Experience }\end{array}$ & Position & Department \\
\hline 1 & Yes & 20 years & $\begin{array}{l}\text { Senior Project } \\
\text { and Building } \\
\text { Manager }\end{array}$ & $\begin{array}{l}\text { Building } \\
\text { Management } \\
\text { Department }\end{array}$ \\
\hline 2 & Yes & 20 years plus & $\begin{array}{l}\text { Building } \\
\text { Executive }\end{array}$ & $\begin{array}{l}\text { Building } \\
\text { Maintenance } \\
\text { Department }\end{array}$ \\
\hline 3 & No & 10 years plus & $\begin{array}{l}\text { Facility } \\
\text { Manager }\end{array}$ & $\begin{array}{l}\text { Building } \\
\text { Management } \\
\text { Department }\end{array}$ \\
\hline 4 & No & 15 years & $\begin{array}{l}\text { Assistant } \\
\text { Building } \\
\text { Manger }\end{array}$ & $\begin{array}{l}\text { Building } \\
\text { Management } \\
\text { Department }\end{array}$ \\
\hline
\end{tabular}

\section{Barriers that Impede Commercial Building Owners to Implement Sustainable} Refurbishment

Table 3 shows that the main issues highlighted by the respondents that need to be considered in the decision making process with regard to building refurbishment. All the respondents agreed that the cost of refurbishment is one of the main issues to be considered. Other issues that need consideration include building age and condition, and tenants' requirements.

Table 3 Decision Making Issues for Building Refurbishment

\begin{tabular}{ll}
\hline 1 & Issues \\
\hline & - Aarket condition, requirements of tenants \\
& - Cost, the return of investment
\end{tabular}




\section{Respondents Opinion Towards Sustainable Practice}

All of the respondents agreed that it is important for commercial buildings to implement sustainable practice. In addition, Respondent 1 and Respondent 2 added that implementation of sustainable practices may reduce the operation cost and avoid unnecessary wastage.

"It is important because each building produces more waste than it can be handled. It produces a lot of waste, and Malaysia has no dedicated recycling program at the moment, which in result all that (waste produced) is going to the landfill and that is just unsustainable" (Respondent 1)

However, Respondent 3 and Respondent 4 both pointed out that implementation of sustainable practices should be focusing more on the new development because older buildings are not equipped and designed for practices, and will require huge amount of capital if they were to be implemented.

"For the old building, it is difficult to convert into sustainable building as the building was not equipped with that type of design. If for new building or new development then it is important. Especially like the TRX (Tun Razak Exchange) project, they are developing one whole new area and hence they should implement sustainable aspect into the project." (Respondent 3)

This indicates that respondents were aware of the importance of sustainable practices. However, they felt that implementation of sustainable refurbishment on existing commercial buildings would require huge commitment from all the parties involved and hence some respondent pointed that sustainable practices should focus on new development.

\section{Cost of Sustainable Refurbishment}

All the respondents agreed that cost is a significant barrier that impede commercial building owners to implement sustainable refurbishment. Respondents mentioned that the cost of implementing sustainable refurbishment is huge and companies normally do not have the financial resources to do so. Respondent 1 pointed out that one of the reasons the company implemented sustainable refurbishment despite the cost was due to requirements by their tenants. Whereas for Respondent 2, it was because the company's corporate social responsibility program requires it.

Respondents 1 and 2, who have had the experience of sustainable refurbishment, both agreed that sustainable refurbishment will have a long payback period. However, Respondent 3 and 4 mentioned that it is a risky 
Md Asrul Nasid Masrom, Mohd Hilmi Izwan, Siow Chan Ann, Sulzakimin M, Kai Chen Goh, \& Azlina

Determining Barriers in Sustainable Refurbishment Projects: Commercial Building Owner Perspectives

investment because in order to recover the investment, the company has to raise the rent and it will risk losing the existing tenants.

\section{Government Initiative on Sustainable Refurbishment}

"I do not see them (government) set the sustainable practice as one of the government project criteria. For instance, government supposed to set all the new government buildings from 2015 onwards must be GBI certificated as an example for the market to follow." (Respondent 2)

The majority of the respondents commented that the government should put more efforts in promoting sustainable building. Lack of effort by the government indicate lack of seriousness on the government side to promote sustainable building practices. This, in turn, makes sustainable refurbishment insignificant in the eyes of building owners.

\section{Expertise in Sustainable Refurbishment}

"No, you can take example of me. Before this I do not know anything about GBI. When I join this company and they want to implement this. Then only I started to learn from there." (Respondent 2)

"Actually, our consultants are all fully aware of GBI. They are all qualified to do this. But the developers do not want to implement this (GBI)." (Respondent 3).

The interview results also indicate that respondents do not feel that lack of expertise is a main barrier that impede the implementation of sustainable refurbishment. As pointed out by Respondent 3, expertise on GBI and, hence, sustainable refurbishment are available. Thus, implementation is up to the building owners.

Similarly, majority of the respondents agreed that the industry is equipped with enough knowledge on sustainable refurbishment. The lack of related knowledge is not a significant barrier that impede sustainable refurbishment implementation.

"It is not easy to change the mindset of people; we tend to follow what our senior did. Hence, even you have the knowledge, but the mindset still the same, then it just needed time." (Respondent 4)

\section{Sustainability Awareness}

"Normally owner will only respond to the tenant or the market trend so it depends on the tenants in the building. If they do not have the awareness and it is not really important to them then the owner will not respond. Building owner will not just be going sustainable voluntary, the tenant has to be pushed." (Respondent 1)

All of the respondents agreed that lack of awareness among Malaysians is one of the barriers that impede sustainable refurbishment. This is because building owners tend to only respond to requirements by tenants. If tenant did not feel, or unaware of, the benefits of sustainable refurbishment, building owners 
would most likely not refurbish the building sustainably.

\section{DISCUSSION}

Figure 1 depicts the difference in respondent insights towards barriers that impede implementation sustainable refurbishment for commercial building in Malaysia. It can be determined that the main barriers that impede sustainable refurbishment of commercial building in Kuala Lumpur are the cost of sustainable refurbishment and the lack of awareness among Malaysian. This is in line with the findings by NAPIC (2012), in which they found that there is a wide gap in terms of awareness on sustainable building practices in Malaysia. Hence, the authorities should focus their efforts on raising the awareness among Malaysian, particularly those who are not directly involved in construction industry. For instance, GBI team should be introduced to the public. On the same note, Leech and Onwuegbuzie (2007) also suggest that the lack of awareness among the owners of building and the costs associated with the sustainable upgrades are the barriers to refurbishment of existing buildings.

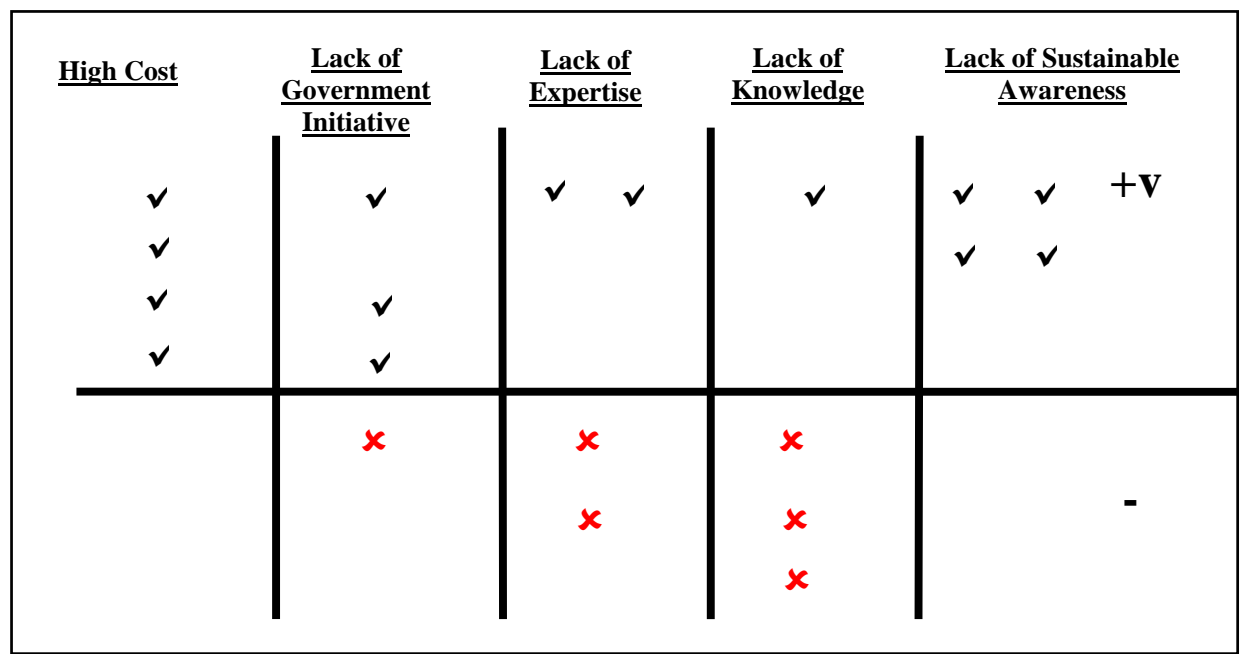

Figure 1 Comparison of Insights of Respondents

\section{CONCLUSION}

The purpose of this study is to investigate the challenges in implementing sustainable refurbishment of commercial buildings. The results obtained from interviews showed that the main barriers that impede commercial owners to implement sustainable refurbishment were cost of sustainable refurbishment and the lack of sustainable awareness among Malaysian. These barriers need to be overcome in order to increase the number of sustainable refurbishment practise in Malaysia. Government must play their roles in promoting sustainable building 
Md Asrul Nasid Masrom, Mohd Hilmi Izwan, Siow Chan Ann, Sulzakimin M, Kai Chen Goh, \& Azlina Determining Barriers in Sustainable Refurbishment Projects: Commercial Building Owner Perspectives

practices. Clients, building owners and building managers must also plan for the refurbishment of their buildings by taking into consideration the economic, social and environmental factors equally.

\section{ACKNOWLEDGMENTS}

The authors would like to thank the Ministry of Education (MOE), Registrar of Universiti Tun Hussein Onn Malaysia, and Department of Construction Management, Faculty of Technology Management and Business, UTHM, for supporting this research.

\section{REFERENCES}

Bruce, T., Zuo, J., Rameezdeen, R., \& Pullen, S. (2015). Factors influencing the retrofitting of existing office buildings using Adelaide, South Australia as a case study. Structural Survey, 33(2), 150-166. https://doi.org/10.1108/SS-05-20140019

CIDB (2015). Construction Quarterly Bulletin 2014. Retrieved from http://www.cidb.gov.my/ index.php/en/construction-info/statistik-industripembinaan/buletin-statistik-pembinaan-suku-tahunan/ construction-quarterlystatistical-bulletin-2014

Malaysia. Energy Commission (2013). Performance and statistical information on electricity supply industry in Malaysia. Putrajaya: Energy Comission.

Green Building Index Organization. (2015). Executive Summary as of 15 February 2015 Retrieved from http://new.greenbuildingindex.org/Files/Resources/e_summary/ 2015/summary\%2002.pdf

Keivani, R., Tah, J. H. M., Kurul, E., \& Abanda, H. (2005). Green jobs creation through sustainable refurbishment in the developing countries (Working Paper 275). Geneva: International Labour Organization.

Leench N. L., \& Onwuegbuzie, A. J. (2007). An array of qualitative data analysis tools: A call for data analysis triangulation. School Psychology Quarterly, 22(4), 557584. http://doi.org/10.1037/1045-3830.22.4.557

Miller, E., \& Buys, L. (2008). Retrofitting commercial office buildings for sustainability: Tenants' perspectives. Journal of Property Investment \& Finance, 26(6), 552561. http://doi.org/10.1108/14635780810908398

National Property Information Centre [NAPIC] (2014). Property Stock Report 2014. Putrajaya: NAPIC.

National Property Information Centre [NAPIC] (2012). Property Stock Report: Commercial Property Stock Table Q4 2014. Putrajaya: NAPIC.

Prodromou, M. K. (2010). The sustainable refurbishment of BK City (Master thesis). TU Delft, Holland.

Riley, M., \& Cotgrave, A. (2005). Construction technology 3. New York: Palgrave Macmillan.

Ryu, H. (2014). Sustainable building refurbishment: Process based approaches with the Hotel Klaus K refurbishment case (Master thesis). Aalto University, Finland.

Sunil, S. (2012). Sustainable refurbishment. Chichester: Wiley-Blackwell. 